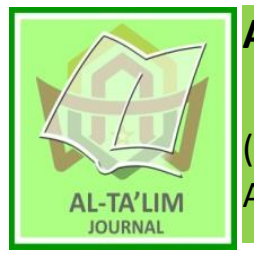

AL-TA'LIM JOURNAL, 25 (2), 2018, (153-162)

(Print ISSN 1410-7546 Online ISSN 2355-7893)

Available online at http://journal.tarbiyahiainib.ac.id/index.php/attalim

\title{
The Students' Perceptions of National Examination Washback: A Case Study at MTS Daarul 'Ulya Metro
}

Received: $17^{\text {th }}$ February 2018; Revised:12 ${ }^{\text {th }}$ March 2018; Accepted: $24^{\text {th }}$ July 2018

Permalink/DOI: http://dx.doi.org/10.15548/ it.v25i2.405

\section{Ahmad Madkur *)}

Institut Agama Islam Negeri Metro,

Lampung, Indonesia.

E-Mail: ahmadmadzkur@metrouniv.ac.id

\section{Dedi Irwansyah}

Institut Agama Islam Negeri Metro,

Lampung, Indonesia.

E-Mail: dedi.irwansyah@metrouniv.ac.id

*) Corresponding Author

\begin{abstract}
Studies on washback of testing have been recently conducted. This demonstrates that there is a growing awareness that testing can have consequences beyond just the classroom. For one decade, Ministry of Education in Indonesia has administered National Examination (NE) as the standardized test for passing grade requirement. In spite of its good aim, NE has become one of controversial issues among educators, students and even parents. Some say yes while some others say no. This paper was mainly attempted to display some impacts, not all, of NE toward the test takers, the students. A qualitative research was employed where the data taken from observation and questionnaires to 20 students. The result of the study showed that most of the students felt unconfident with their score in National Examination due to the fact that their English competence was considered low. However, the difficulty of NE did not significantly affect their studying English language. In other words, the washback of $\mathrm{NE}$ on their study was negative.
\end{abstract}

Key words: Washback; national examination; students' perceptions

How to cite: Madkur, A., \& Irwansyah, D. (2018). Students' perceptions of national examination washback: A case study at MTS Daarul 'Ulya Metro. Al-Ta Lim Journal, 25(2). doi:http://dx.doi.org/10.15548/jt.v25i2.405

\section{INTRODUCTION}

Testing is one of the common ways to assess. Assessment is perhaps one of most difficult and important parts of teachers' jobs (Shepard, 2000; Wiggins, 2011). Ideally, it should be seen as a means to help the teachers guide their students on their road to learning. No single procedure can meet the needs of all learners and situations, so according to (Black \& Wiliam, 2006; S. Brown, 2005; James, 2008), the teachers need to remember to incorporate a variety of tools to help the students know how they are progressing and to gauge the effectiveness of our own methodology and materials.
Testing and teaching are inseparable. Testing and teaching, as highlighted by Sun (2013), are so closely related that it is virtually impossible to work in either area without being constantly concerned with the other. Testing must accompany all kinds of teaching, including English language teaching, and reflect how much English knowledge students have grasped in a certain phase of English study. Tests should be constructed primarily to reinforce learning, to motivate students, and to assess students' performance in language acquisition. Thus, it is necessary for instructors to design tests according to the features of the college English intensive 
reading course in order for validity and reliability to occur.

Tests and test results have a significant impact on the career or life chances of individual test takers (e.g. access to educational/employment opportunities). They also impact on educational system and on society more widely: for example, test results are used to make decisions about school curriculum planning, immigration policy, or professional registration for doctors; and the growth of a test may lead publishers and institutions to produce test preparation materials and run test preparation courses.

In Indonesia, the government has administered a nationally undertaken test called National Examination (NE) since 2005. It is an evaluation standard system for elementary and secondary education (Aprianto, 2013; Inggris, 2015; Saukah, 2015; Sulistyo, 2014). The standard is no difference among all provinces in Indonesia. The test includes three subjects namely Bahasa Indonesia, Math, and English. During its implementation, there have been several changes of score standard. The year of 2014, the minimum score for each subject was 4.00 and the minimum of the average score is 5.50 .

$\mathrm{NE}$ is generally aimed at increasing the quality of education through deciding the same score (cut off score). Unfortunately, since it is equally treated to all students in Indonesia, it gives birth to some negative impacts to almost all stakeholders of education. In particular, it affects the students' perceptions since they are the test takers. As a consequence, the national examination attracts some pros and cons from different group of people (Andrews, 2004; Cheng, 2008).

Due to the highly essential role of testing in students' learning including English language and the occurrence of pros and cons on the NE, it is urgent to really pay big attention to the students' thoughts on national examination in order to reduce the negative impacts and also the barriers of doing NE faced by the students. Therefore, this research was done to know the washback of NE on the students (Bailey, 1999; Cheng \& Watanabe, 2004; Ferman, 2004).

\section{Testing and Teaching}

Testing has been widely implemented for many kinds of purposes such as passing requirements, university entrance, and more importantly periodic evaluation of students' learning. Meanwhile, teaching is an attempt to deliver knowledge to the learners. Even though the two terms are different, they are interconnected (Curtis \& Cheng, 2004; Graves, 2002). Teaching is aimed at making the students understand certain subjects. Then, to know whether teaching process is successful or not, the teachers conduct testing activity. In other words, through testing, how far the students understand the lesson can be found out. Therefore, it can be drawn that teaching and testing are inseparable in that both of them have interconnected relationship.

Testing is the practice of making objective judgments regarding the extent to which the system (device) meets, exceeds or fails to meet stated objectives. Through testing, furthermore, the teachers can formulate their educational judgment. Then, because most of the teachers' time is spent to teach in the class, classroom tests are undoubtedly needed to conduct regularly. The core reason behind taking these tests is that they can give the teachers insight of each student of the class. Consequently, there is always the need to administer the test effectively.

When it comes to language testing, it has been observed the narrow scopes of tests and felt the greater investigation beyond test within the periphery of assessment. If English language testing is aimed at the greater strength of communication, assessment must have nexus with real-world experiences. The figure below shows how 
test, measurement and teaching relate one another.

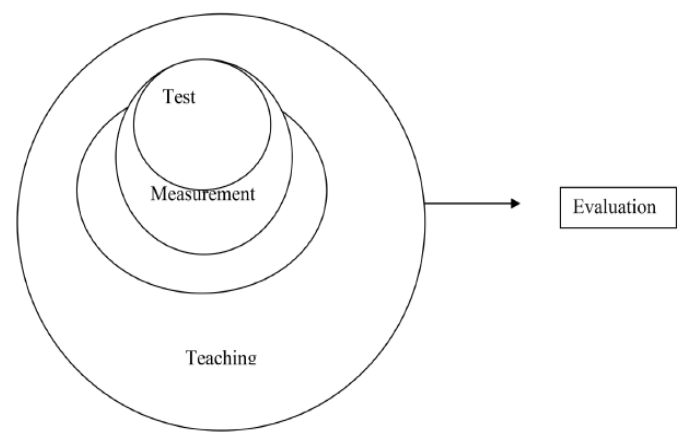

Figure 1. The Venn diagram shows the relationship among teaching, assessment, measurement, test and evaluation.

In relation with the wash back of testing, two studies conducted by AmengualPizarro (2009); Spratt (2005) show in detail what areas in teaching and learning affected by wash back, namely curriculum, materials, teaching methods, feelings and attitudes, learning, teaching strategies and teaching contents.

A good test has several important characteristics, namely reliability, validity and practicality. The factors influencing the test reliability are environment, administration, scoring and number of test items. Then, test cannot achieve validity when it is testing external knowledge, not representative sample and irrelevant to the objective of the course. Meanwhile, when the test has already been reliable and valid, the next consideration, which also has big urgency, is test practicality. In order to be practical, test administrator must pay big attention to the budgeting, ease of test construction and ease of scoring.

\section{What is Washback?}

According to Burrows (2001); Cheng \& Watanabe (2004); Taylor (2005), washback is generally defined as being either negative or positive. Negative washback is said to occur when a test's content or format is based on a narrow definition of language ability, and so constrains the teaching/learning context. For example, when learning grammar, the students are asked only to memorize part of speech, but when the test comes, they must make a complete sentence. Positive washback is said to result when a testing procedure encourages 'good' teaching practice; for example, an oral proficiency test is introduced in the expectation that it will promote the teaching of speaking skills.

Some ask about what is between washback and impact because these two words can be understood as effect of influence. Wall as cited by Thaidan (2015) differred the test impact from washback terms. In terms of effects concerns, the impacts denotes to "any of the effects that a test may have on individuals, policies or practices within the classroom, the school, the educational system or society as a whole" (Andrews, 2004; Cheng, 2008; Cheng \& Watanabe, 2004; Curtis \& Cheng, 2004; Watanabe, 2004b). Whereas backwash according to Hughes stand of views that, "the effect of testing on teaching and learning" ( $\mathrm{J}$. D. Brown, 2005)

To make the study of washback useless, Davidson \& Fulcher (2009); Shibliyev \& Gilanlığlu (2009) believe that, "If the concept of washback is to have any meaning, it is necessary to identify what changes in learning or teaching can be directly attributed to the use of the test in that context". Meaning to say, the test must really refelct the instructional activities.

\section{Why does Washback Need to be studied?}

Since washback can affect the classroom activities, teachers must pay a big attention to this. Hamp-Lyons (1997); Watanabe (2004a) maintained that washback cannot only be referred to the effect of an examination in the classroom, but also in the school, in the educational system and in the society as well. Besides, this effect does not always take place unswervingly but it is mediated by a number of factors, like the teachers' perception of the test, the status of the test as well as that of the subject - matter tested, the macro - context where the examination is 
used, the purpose of learning the language in the context, among others. Furthermore, in order to study the washback effect, it is necessary to look at the people that participate in the educational process, to the actual classroom events and activities, and to the outcomes of these processes.

The importance of teachers in washback processes is emphasized by Alderson and Wall as cited by (Shaoshan, 2005) in several of their restatements of the washback hypothesis.

1. A test will influence teaching.

2. A test will influence what teachers teach; and

3. A test will influence how teachers teach.

4. A test will influence the rate and sequence of teaching; and

5. A test will influence the degree and depth of teaching; and

6. A test will influence attitudes to the content, method, etc. of teaching and learning.

In line with the above-mentioned statement, the students and teachers' perceptions on washback have correlation with examination preparation. The preparation is surely related to teaching methodology, learning strategies and the choice of materials.

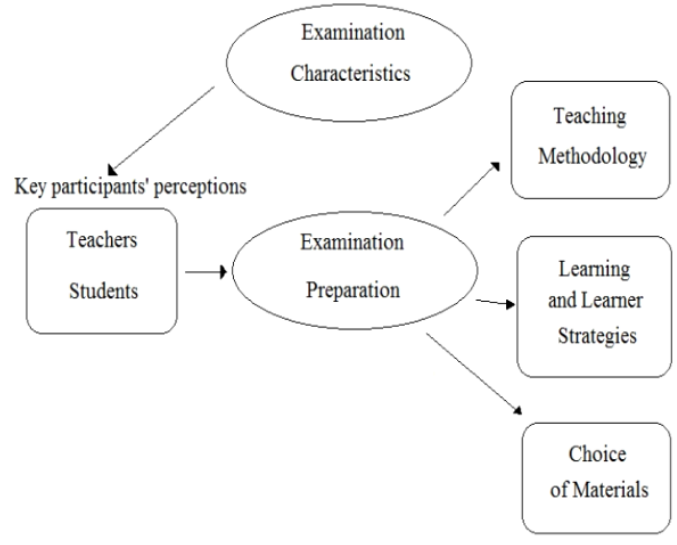

Figure 2. Conceptual model of washback

The figure shows us that the washback of testing will influence how the teachers prepare the test, how they teach, and how they select the learning materials.

\section{Washback Effect of Testing}

English language teaching in Indonesia has been a big concern due to its complexity. Jabbarifar (2009) stated that a major concern of teaching English language for teachers has been assessing and evaluating students' progress during their courses of study as well as their classroom achievements at the end of it. Despite the highly useful aspects of tests Roediger III, Putnam, \& Smith (2011) such as multiple choice test, essay test and paragraph reading, teachers have not been successful in the classroom.

In field of testing, the impacts are recognized as wash back effects. Meanwhile, wash back is the influence of testing on teaching and learning (Cheng \& Curtis, 2004; Cheng, 2005; Fulcher \& Davidson, 2007). In addition, it can be defined as the effects of language tests on micro-level of language teaching and learning, i.e. inside the classroom (Bachman, 2000). Meanwhile, Brown (2005) highlights that washback is the degree to which a test affects the curriculum that is related to it.

Shohamy (2006) summarizes four key definitions that are useful in understanding the washback concept: 1) Washback effect refers to the impact that tests have on teaching and learning; 2) Measurement driven instruction refers to the notion that tests should drive learning; 3) Curriculum alignment focuses on the connection between testing and the teaching syllabus; and 4) Systemic validity implies the integration of tests into the educational system and the need to demonstrate that the introduction of test can improve learning. Tests can also have effect beyond the classroom. The wider effects of tests on the community as a whole, including the school, is referred to a test impact (Muñoz \& Álvarez, 2010; Pan, 2016).

Watanabe as cited in Cheng \& Watanabe (2004) conceptualizes wash back as having the following dimensions:

1. Specificity: wash back may be general or specific. General wash back means a type of effect that may be produced by any test; 
specific wash back refers to a type of wash back that relates to only specific aspect of a test or one specific test type.

2. Intensity: wash back may be strong or weak. If the test has a strong effect, then it will determine everything that happens in the classroom, and will lead all teachers in the same way toward exams. On the other hand, if a test has a weak effect, then it will affect only a part of the classroom events, or only some teachers and students, but not others.

3. Length: the influence of exams, if it is found to exist, may last for a short period of time, or for a long time.

4. Intentionality: Messick as cited in Cheng \& Watanabe (2004) implies that there is unintended as well as intended wash back when he wrote that judging validity in terms of whether a test does the job it is employed to do...requires evaluation of the intended or unintended social consequences of test interpretation and use.

5. Value or direction: examination wash back may be positive or negative.

\section{National Examination (NE)}

The National Examination, which in Bahasa Indonesia is called Ujian Nasional abbreviated into $\mathrm{NE}$, is the latest form of a school leaving examination in Indonesia starting from 2005 until now. It can be defined as a test to measure and evaluate the students' competence nationally by the central government after the process of teaching and learning.

The constitution of the Republic of Indonesia number 20 of 2003 states that, in order to control the quality of education nationwide to be evaluated as a form of accountability of education providers to the parties concerned. Further stated that the evaluations conducted by independent agencies on a regular basis, comprehensively, transparently, and systematically to assess the achievement of national education standards and the monitoring process evaluation should be done continuously.
Evaluation of the monitoring process is carried out continuously and continuous in the end will be able to fix the quality of education. Improving the quality of education begins with the determination of the standard. Determination standards continue to rise is expected to encourage increased quality of education, which is the determination of educational standards is the determination of the limit value (cut-off score).

The following is the score standard changes since 2005 until now:

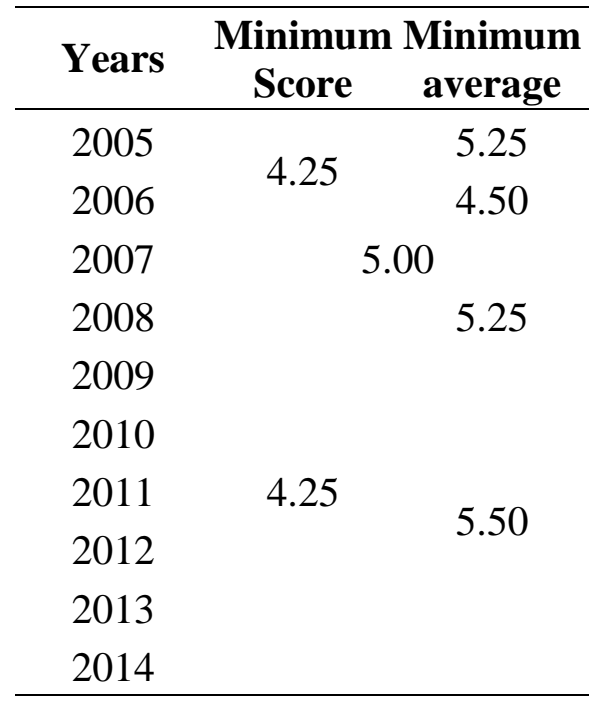

Despite of its good purpose, National Exam has been subject of controversy since its inception. It became notorious for answer key leakage, cheating, fraud, and corruption. Some argue that the exam is too hard and demanding for students and teachers. Schools are forced to allocate more time for drilling students, putting more workload to both teachers and students. National Exam fail rate is usually very low. Critics argue that it did not give an accurate picture about Indonesian student's real competency, because of cheating problems and other issues.

Several studies related on wash back of testing on teaching and learning has already been conducted. A study by Gholami \& Moghaddam (2013) investigated that students take weekly quizzes performed better than the group without quizzes in the 
final achievement tests. Meanwhile, Sukyadi \& Mardiani (2011) study shows that the English National Examination has an influential impact on teachers' teaching in the aspect of: activity/time arrangement, teaching materials, teaching contents, teaching methods, teaching strategies, ways of assessing, and on the feelings and attitudes of the students. Pan (2009) drew washback and its implementations in pedagogical activities. She found that tests can become factors that the teacher to "teach to the test", and what students learn might be discrete points of language, not the communicative part of language they need in real life.

Furthermore, Burrows as cited from Cheng and Watanabe (2004) revealed the effect of classroom-based assessment in the Australian Migrant English Program (AMED). She concluded that the assessment affected the curriculum innovation at least in terms of teacher's response. Completing what Sukyadi and Mardiani had already discovered in the effect of English National examination, this present study offered a wider object because the writer studied the national examination in general not partial. It took a part in enriching the supply of researches of testing wash back on the students' thoughts and behaviors.

\section{METHOD}

This research was presented in qualitative approach. How the students conceived of National Examination was investigated. To get this data, the participants were asked to respond some statements in questionnaire. The students involved in this research were 20 students of MTs Daarul 'Ulya Metro in academic year of 2013/2014.

After collecting the data, Miles and Huberman Model was employed to process data. When implementing this model, the writer did the following steps:

1. The writer gathered all data which are used to complete the research. Some of the documents about the students, the teachers and the school were photocopied.
Then the students' perceptions on the NE were explored through the questionnaire.

2. The writer classified the data by summarizing and grouping specific things using coding and tabulation.

3. To display the data, the writer then used graphics, figures, or charts. The display was meant to describe the content of the entire data.

4. Lastly, the writer verified his research by making conclusion of data findings.

\section{RESULT AND DISCUSSION}

MTs Daarul 'Ulya is a pesantren-based secondary school located in Jl Merica no. 31 Iring Mulyo Metro Timur, Metro Lampung. Because of its establishment under the Islamic-based foundation, it included several local content subjects which were not taught in public schools. The majority of the students are living in a dormitory. Male and female students are therefore separated in different building. Since it was founded in 2009, MTs Daarul 'Ulya has involved the ninth grade students in taking National Examination for four times. Even though no one was failed in passing the national exam during these four years, it was not without many barriers and problems.

The problems which always occur every year were, among others, the diversity of the students' competence. Most of them found it difficult to fulfill the standard of passing grade. The other problem was about the preparation for facing the NE. Because they were also scheduled to have many classes in the pesantren with a number of lessons different from the lessons they got in the school. They usually cannot manage well to study more the subject tested. Moreover, they were usually too tired of full schedule so that they felt lazy to review their lessons. Regarding with the preparation of $U N$, the school attempted to reduce the existing problems. One of the efforts was giving the third-year students some additional classes after school hours. The classes were specialized for enabling the students to face the final examination. 


\section{The Students' Perception on UN in General}

From the result of questionnaire, the students' general perception on national examination can be categorized into two, positive and negative. To know the positive washback of $\mathrm{NE}$ on the students, five statements were proposed through the questionnaire. The statements are:

1. I feel relaxed of thinking about National Examination.

2. I feel confident to my ability in doing national examination.

3. I feel more motivated to study because of national examination.

4. Although National Examination is difficult, I still can sleep well.

From the four statements and 80 responses, there were 12 responses of strongly agree (sangat sesuai/SS), 13 responses of agree (sesuai/S), 18 responses of less agree (kurang setuju/KS), 24 responses of disagree (tidak setuju/TS) and 13responses of strongly disagree (sangat tidak sesuai). The following chart is to illustrate the distribution of the responses.

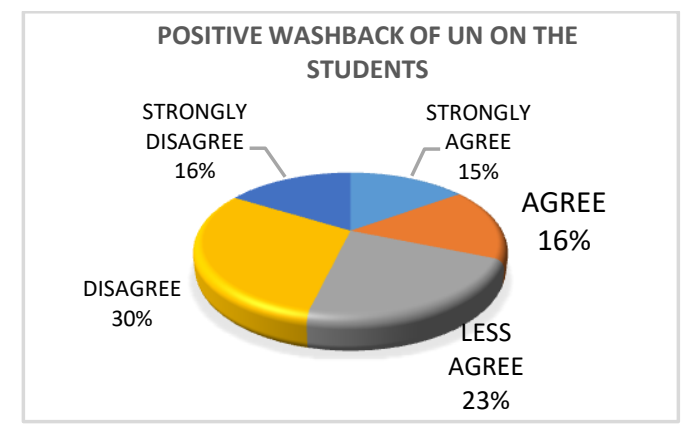

Chart 1. The students' positive perception on National Examination

From the chart I it can be seen that 30 percent of the participants disagree to the statements telling the students the positive wash back of national examination. For example, the statement "I become more motivated because of national examination" gained only 2 agreements and 0 strong agreement. In contrast, there were 7 disagreements and 8 strong disagreements for the statement. In other words, it is not a good idea to say that National Examination is to motivate the students to study more.

Then, to know the negative washback of National Examination on the students, five statements were then proposed. They are:

1. National Examination makes me not concentrated to study.

2. I am restless when National Examination is getting closer.

3. I am afraid of my low ability to answer questions in National Examination.

4. I feel pessimist with my score of National Examination.

5. Thinking about National Examination makes me skittish.

From five statements about negative wash back of NE and 100 responses, there were 24 responses of strongly agree (sangat sesuai/SS), 33 responses of agree (sesuai/S), 19 responses of less agree (kurang setuju/KS), 17 responses of disagree (tidak setuju/TS) and 7 responses of strongly disagree (sangat tidak sesuai). To see more clearly the difference among the responses, the chart II is displayed.

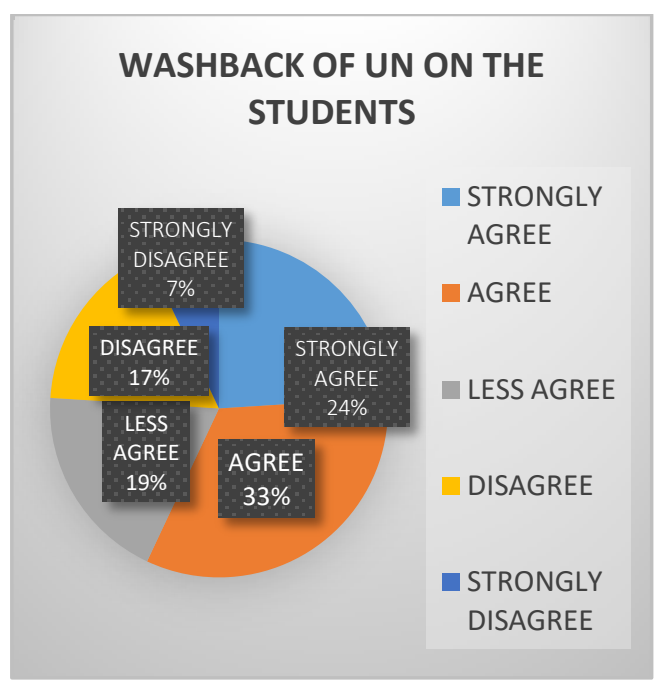

Chart 2. The students' negative perception on National Examination

It can be seen that $33 \%$ participants agreed and $24 \%$ participants strongly agreed that National Examination gives birth to negative impact. On the contrary, only $17 \%$ participants and $7 \%$ participants who disagreed that statement. To summarize, most students (more than 50\%) agreed that 
there were some bad effect of national examination on the students.

\section{The Students' Perception on English Examination}

To enrich the result of the research, especially in English examination, the writer added four statements to figure out the students' perception on one of obligatory lessons of national examination. Therefore, four statements were then given to the participants.

1. The most difficult NE lessons is English.

2. I feel confident with my score of English subject.

3. English is the easiest subject in National Examination.

4. I take an additional English class to get good grade in National Examination.

The first and the fourth statement "The most difficult NE lessons is English "and "I take an additional English classes to get good grade in National Examination" gained 11 responses of strongly agree, 8 responses of agree, 4 responses of less agree, 10 responses of agree and 7 responses of strongly agree. This means that more than 50 $\%$ (if we include the response of less agree) still find English subject difficult and consequently take additional class to increase their ability.

The second and third statement got 0 response of strongly agree, 7 responses of agree, 12 less agree, 13 disagree and 8 strongly disagree. From the responses, it can be understood that the students who feel confident with their English ability is less than those who have low ability in English.

\section{CONCLUSION AND RECOMMENDATIONS}

Based on the investigation through the responses made by 20 students of MTs Daarul 'Ulya, it can be understood that National Examination (NE) more causes negative wash back than generates the positive one. From the findings of this study, most the students seem disturbed by NE in term of feelings, thoughts and attitudes. In particular, the features triggering them are the standard of passing grade, the fact that $\mathrm{NE}$ determines a lot their graduation, and the questions' level of difficulty.

Regarding to English, which is one of subjects tested on NE, most students in the school did not find English the most difficult subject. Nevertheless, most of them feel unconfident with their score in National Examination due to the fact that English is still considered demanding by the Indonesian students. The importance of NE was not significantly influential on their studying English language.

Based on the findings of the present study, the writer would like to give following suggestions:

1. National Examination can be made one of the requirements of students' graduation; nevertheless what happens now is that it plays too big portion. Therefore, government is expected to lessen the role of NE and increase the role of School Examination.

2. Since there are a lot of schools, especially in remote areas, which is lack of educational facilities, the government must solve this problem by giving them real help and attention. Because if no, the equal ability of the students is very difficult to achieve.

3. The teachers, particularly who teach National Examination subjects, must always improve their competence so that they can transfer adequate knowledge and concise guidance to make the students pass the examination.

4. The students must be really well-prepared before doing the National Examination so that their worries.

\section{REFERENCES}

Amengual-Pizarro, M. (2009). Does the English Test in the Spanish university entrance examination influence the 
teaching of English? English Studies, 90(5), 582-598.

Andrews, S. (2004). Washback and curriculum innovation. In Washback in language testing (pp. 59-72). Routledge.

Aprianto, K. (2013). Validity and washback of english tests in the national examination. English Education Journal, 3(1).

Bachman, L. F. (2000). Modern language testing at the turn of the century: Assuring that what we count counts. Language Testing, 17(1), 1-42.

Bailey, K. M. (1999). Washback in language testing. Educational Testing Service Princeton, NJ.

Black, P., \& Wiliam, D. (2006). Assessment for learning in the classroom. Assessment and Learning, 9-25.

Brown, J. D. (2005). Testing in language programs: a comprehensive guide to English language assessement. McGraw-Hill College.

Brown, S. (2005). Assessment for learning. Learning and Teaching in Higher Education, (1), 81-89.

Burrows, C. (2001). Searching for washback: The impact of assessment in the certificate in spoken and written English. Studies in Immigrant English Language Assessment, 2, 95-187.

Cheng, L. (2008). Washback, impact and consequences. In Encyclopedia of language and education (pp. 24792494). Springer.

Cheng, L., \& Watanabe, Y. (2004). Washback in language testing: Research contexts and methods. Routledge.

Curtis, A., \& Cheng, L. (2004). Washback or backwash: A review of the impact of testing on teaching and learning. In
Washback in language testing (pp. 25-40). Routledge.

Davidson, F., \& Fulcher, G. (2009). Language Testing and Assessment: An Advanced Resource Book (Kindle Edition ed.). New York, USA: Routledge Applied Linguistics.

Ferman, I. (2004). The washback of an EFL national oral matriculation test to teaching and learning. Washback in Language Testing: Research Contexts and Methods, 191-210.

Gholami, V., \& Moghaddam, M. M. (2013). The effect of weekly quizzes on students' final achievement score. International Journal of Modern Education and Computer Science, 5(1), 36.

Graves, D. H. (2002). Testing is Not Teaching: What Should Count in Education. ERIC.

Hamp-Lyons, L. (1997). Washback, impact and validity: Ethical concerns. Language Testing, 14(3), 295-303.

Inggris, D. I. T. P. B. (2015). Ujian Nasional di Indonesia dan implikasinya terhadap pembelajaran Bahasa Inggris. Jurnal Penelitian Dan Evaluasi Pendidikan, 19(2), 243-255.

Jabbarifar, T. (2009). The importance of classroom assessment and evaluation in educational system. In Proceedings of the 2nd International Conference of Teaching and Learning (pp. 1-9).

James, M. (2008). Assessment and learning. In Unlocking assessment (pp. 34-49). David Fulton Publishers.

Muñoz, A. P., \& Álvarez, M. E. (2010). Washback of an oral assessment system in the EFL classroom. Language Testing, 27(1), 33-49.

Pan, Y.-C. (2016). A review of washback and its pedagogical implications. $V N U$ 
Journal of Science: Foreign Studies, 25(4).

Roediger III, H. L., Putnam, A. L., \& Smith, M. A. (2011). Ten benefits of testing and their applications to educational practice. In Psychology of learning and motivation (Vol. 55, pp. 1-36). Elsevier.

Saukah, A. (2015). National Exam in Indonesia and its washback effects. Developing Indigenous Models of English Language Teaching and Assessment, 143-160.

Shaoshan, L. (2005). The washback of language testing and language testing design [J]. Foreign Language World, 1,013 .

Shepard, L. A. (2000). The role of assessment in a learning culture. Educational Researcher, 29(7), 4-14.

Shibliyev, J., \& Gilanlığlu, İ. (2009). Language testing and assessment: An advanced resource book. Oxford University Press.

Shohamy, E. (2006). Language policy: Hidden agendas and new approaches. Routledge.

Spratt, M. (2005). Washback and the classroom: The implications for teaching and learning of studies of washback from exams. Language Teaching Research, 9(1), 5-29.
Sukyadi, D., \& Mardiani, R. (2011). The washback effect of the English national examination (ENE) on English teachers' classroom teaching and students' learning. Kata Lama, 13(1), 96-111.

Sulistyo, G. H. (2014). Ujian Nasional (UN): harapan, tantangan, dan peluang. Wacana, Journal of the Humanities of Indonesia, 9(1).Sun, L. (2013). Thoughts on College English Testing. Journal of Language Teaching \& Research, 4(5).

Taylor, L. (2005). Washback and impact. ELT Journal, 59(2), 154-155.

Thaidan, R. (2015). Washback in language testing. Education Journal, 4(1), 5-8.

Watanabe, Y. (2004a). Methodology in washback studies. In Washback in language testing (pp. 41-58). Routledge.

---. (2004b). Teacher factors mediating washback. In Washback in language testing (pp. 151-168). Routledge.

Wiggins, G. (2011). A true test: Toward more authentic and equitable assessment. Phi Delta Kappan, 92(7), 81-93. 